\title{
The impact of changes in the volume of freight and passenger transportation by water on the GDP of Ukraine
}

\author{
Vadym Gryshchenko ${ }^{1, *}$, and Iryna Gryshchenko ${ }^{1}$ \\ ${ }^{1}$ Institute of Market Problems and Economic-Ecological Research of the National Academy of \\ Sciences of Ukraine, Department of transport market, 65044 Odesa, Ukraine
}

\begin{abstract}
The purpose of the article is to analyse the relationship between the GDP volume index and the volume of freight and the number of passengers transported by water in Ukraine in the system of sustainable development goals. The article examines the dynamics of changes in GDP and the situation in the field of maritime and inland water transport in Ukraine. This provided an opportunity to develop an economic and mathematical model of the relationship between the GDP volume index, the volume of freight, and the number of passengers transported by water in Ukraine. Based on the developed economic and mathematical model, the authors predict possible changes in the GDP volume index under the influence of changes in the volume of freight and passenger transported by water transport in Ukraine. The authors propose to increase the values of indicators 9.1.2 and 9.1.3 in the framework of task 9.1 (SDG 9) precisely by increasing the volume of transportation of goods and passengers by water transport. According to the authors, this is most consistent with the conditions of target indicator 8.1.1 (SDG 8) increasing.
\end{abstract}

\section{Introduction}

Gross domestic product is one of the most important indicators of economic development. This indicator better than others expresses the level of economic development of the world. It characterizes the result of production activities in the field of both tangible and intangible production and can be used as an indicator of the welfare level of any country. Numerous scientific works of domestic and foreign authors are devoted to topical issues of sustainable economic development (B. Burkynskyi, N. Khumarova, M. Petrushenko, H.Shevchenko [1]), business development (O. Laiko, S. Kovalenko, O. Bilousov [2]), transport economics (P. Kelle, J. Song, M.Jin, H. Schneider, C. Claypool [3], S Ilchenko. [4], C.-Y.Wu, I. Heiets, H. Shvindina [5]), and economic modeling (V. Koval, S. Kotenko, et al. [6-9]) in the system of environmental and economic security (V. Gryshchenko, O. Dreval, I. Gryshchenko [10]). At the same time, further research is needed to determine the relationship between the GDP volume index and the volume of freight and the number of passengers transported by water in Ukraine in the system of sustainable development goals.

* Corresponding author: v.f.gryshchenko@gmail.com 
According to the voluntary national review "Sustainable Development Goals: Ukraine" $[11,12]$, SDG 9 "Industry, Innovation and Infrastructure" is of special importance for creating the preconditions for GDP growth (indicator 8.1.1, SDG 8) and value-added. It includes target 9.1 "Develop quality, reliable, sustainable and accessible infrastructure based on the use of innovative technologies, including ecologically clean means of transport". Separate indicators of this target are indicators 9.1.2 "Volume of transported goods" and 9.1.3 "Number of passengers". If we consider the GDP of Ukraine by income categories [13], the share of transport among the whole range of economic activities is $9 \%$ of wages (third place after the processing industry - 16\%, trade, public administration, and defense $-13 \%$ respectively); $10 \%$ of the total amount of taxes paid (4th place after the industry $-20 \%$, trade $-17 \%$, financial and insurance activities - $11 \%$ ); $7 \%$ of the gross profit (6th place after agriculture - $21 \%$, trade - $17 \%$, industry - $13 \%$, real estate $-11 \%$ and mining - 8\%); $19 \%$ of the subsidies, related to production (second place after art, sports, entertainment, and recreation - 24\%). Given the above, the purpose of the article is to analyze the relationship between the GDP volume index, the volume of goods and the number of passengers transported by water in Ukraine in the system of sustainable development goals.

\section{Methodology}

The theoretical and methodological basis of the study was the fundamental scientific provisions of general economic theory and transport economics in the system of sustainable development goals. The following methods were used to solve the tasks in the study: comparative and structural analysis - in the research of the current state and prospects of increasing the GDP volume index, the volume of goods, and the number of passengers transported both by maritime and inland water transport; correlation-regression analysis in determining the impact of the volume of goods, and the number of passengers transported by water transport on the GDP volume index change in Ukraine; calculation and analytical method - in forecasting the values of the GDP volume index (indicator 8.1.1, SDG 8) depending on the volume of goods (indicator 9.1.2, SDG 9) and the number of passengers (indicator 9.1.3, SDG 9) which transported by water transport in Ukraine.

\section{Results}

The essence of the study is to analyse the dynamics of changes in GDP and the situation in the field of maritime and inland water transport in Ukraine; to develop an economic and mathematical model of the relationship between the GDP volume index, the volume of goods, and the number of passengers transported by water in Ukraine; to predict, based on the developed economic and mathematical model, possible changes in the GDP volume index (indicator 8.1.1, SDG 8) under the influence of changes in the volume of goods and number of passengers transported by water in Ukraine (indicators 9.1.2 and 9.1.3, SDG 9).

\subsection{Dynamics of change in GDP}

In Ukraine, the volume of GDP per capita in 2019 was about 3,659 US dollars, which is only $9.4 \%$ of the level of GDP per capita in the EU - 38,984.69 US dollars $[14,15,16]$. Note that the highest figure in Ukraine was in 2013 and amounted to 4,029.71 US dollars per capita (approximately $10.3 \%$ of the EU level), the lowest value was observed in 1999 and 2000, and amounted to 635.7 US dollars per capita (nearly $2.8 \%$ of the EU level). The highest value of real GDP in Ukraine took place in 2008 and 2013 and amounted to about 
179.82 and 183.31 billion US dollars, respectively. The largest annual growth of Ukraine's real GDP was in $2001(+9.2 \%), 2003(+9.52 \%)$ and $2004(+12.11 \%)$. The lowest value of real GDP in Ukraine was observed in 2000 and amounted to 31.26 billion US dollars. The fastest real GDP of Ukraine decreased from 1990 to 1999 (-22.93\% in 1994), in 2009 ($14.76 \%)$ and from 2014 to 2015 (-9.77\%). In recent years, Ukraine's real GDP has shown an upward trend from $2.24 \%$ in 2016 to $3.23 \%$ in 2019 with an absolute value of 153.78 billion US dollars (Fig. 1).

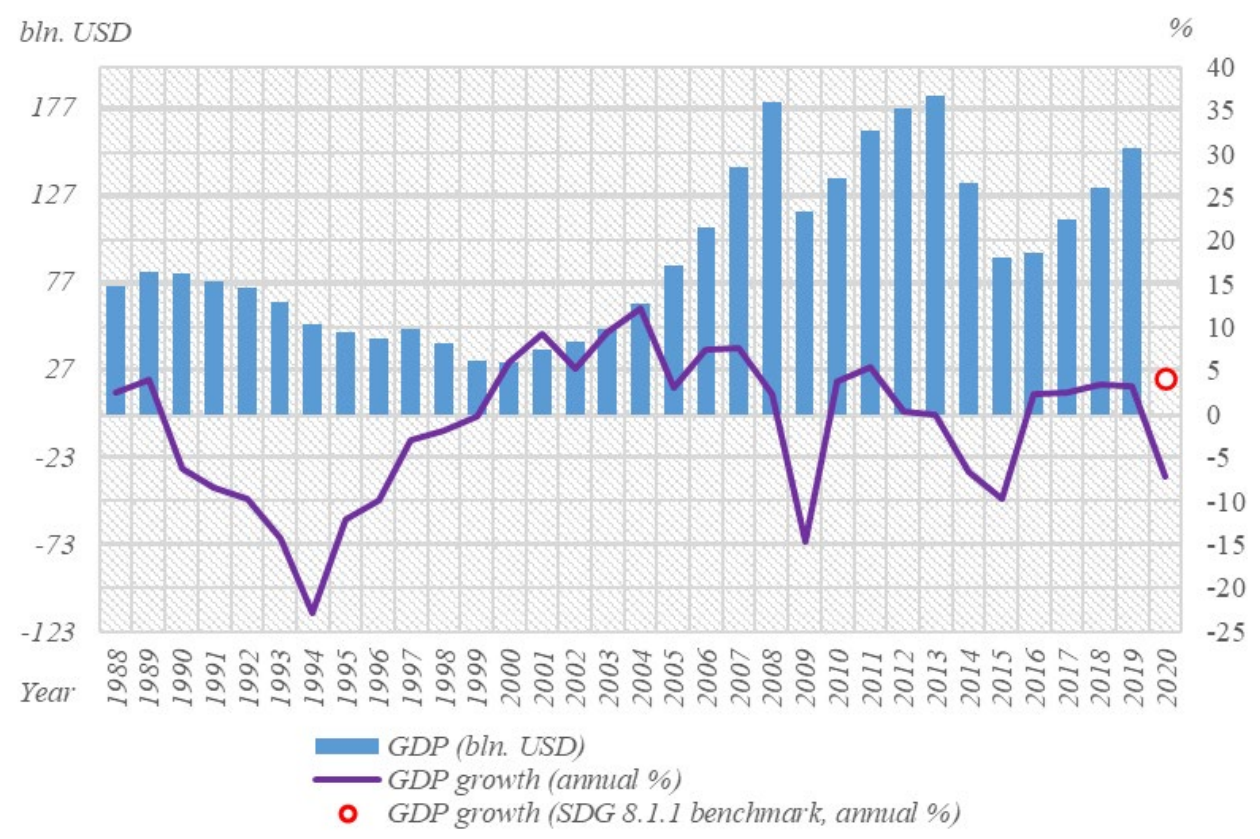

Fig. 1. Changes in GDP of Ukraine.

The COVID-19 pandemic began at the beginning of 2020. It caused significant changes in the economic activity of both Ukraine and many countries around the world. Emergency quarantine restrictive measures have been introduced. Such steps have led to a slowdown in economic development. Thus, the volume of world trade decreased by $13.4 \%$. The real GDP of high-income countries decreased the most (-8.3\%). The real GDP of low-income countries decreased the least $(-4.4 \%)$. The largest decrease of real GDP was observed in the EU - by $10.1 \%$, Latin America - by $9 \%$, and South Asia - by $8.2 \%$. [17]. In the current economic conditions complicated by the COVID-19 pandemic, Ukraine is experiencing a slowdown in economic development. According to the State Statistics Service of Ukraine, in 2020 the following changes in the volume of the gross domestic product took place: I quarter - (-1.3\%), II quarter - (-11.4\%), III quarter - (-3.5\%) [16]. According to the Ministry for development of Economy, Trade, and Agriculture of Ukraine [18] in January-June 2020 , Ukraine's GDP decreased by $6.5 \%$, and in general, according to the results of 2020 , GDP is projected to fall to $-4.8 \%$. This is also evidenced by the data presented in the Global economic prospects report [17], according to which in 2020 the GDP growth rate in Ukraine should decrease and equal approximately $-7.2 \%$ against a growth of $3.2 \%$ in 2019 , which corresponds to global trends. The dynamics of changes in the real GDP of the world in the regional context are shown in the Fig. 2. 
In addition to the above, other potential factors contribute to the slowdown in achieving the goals of sustainable development (in particular SDG 8) in Ukraine. One of such factors is the "fiscal crisis", which is facilitated by a fairly high level of economic activity in taxfree parts of the economy. Analysis of analytical materials and statistics of the National Bank of Ukraine [19], the Ministry for Development of Economic, Trade, and Agriculture of Ukraine [20], and our own experience suggests that almost $23.8 \%$ of Ukraine's official GDP is in the shadows, of which about $19.7 \%$ of GDP is the cash shadow economy and $4.1 \%$ of Ukraine's GDP is domestic production of goods for own final consumption (nonmonetary shadow economy), although it is worth to add almost $14.4 \%$ of Ukraine's GDP as cash settlements initiated by sellers and service providers, i.e. a "passive shadow economy". Experts of the Department of strategic planning and macroeconomic forecasting of the Ministry for Development of Economic, Trade, and Agriculture of Ukraine [20] attribute the shadowing of Ukraine's economy to the fact that some factors such as: "low level of protection of property rights; ... imperfection of the country's judicial system..., as a consequence, a low level of public confidence in it; high level of corruption in the country...; preservation of challenges for ensuring the stable functioning of the country's financial system...; the existence of territories not under the control of the Government, formed during the armed conflict on the territory of the country, and, as a consequence, the growth of "potential opportunities" for the emergence of new schemes of goods smuggling. This creates potential financial risks for businesses that work "on the white" and greatly slows down their innovative development, as they are forced to compensate for the disproportionately large number of gaps in total tax revenues to budgets of different levels in contrast to the shadow economy, which, for one reason or another, is beyond the reach of fiscal authorities.

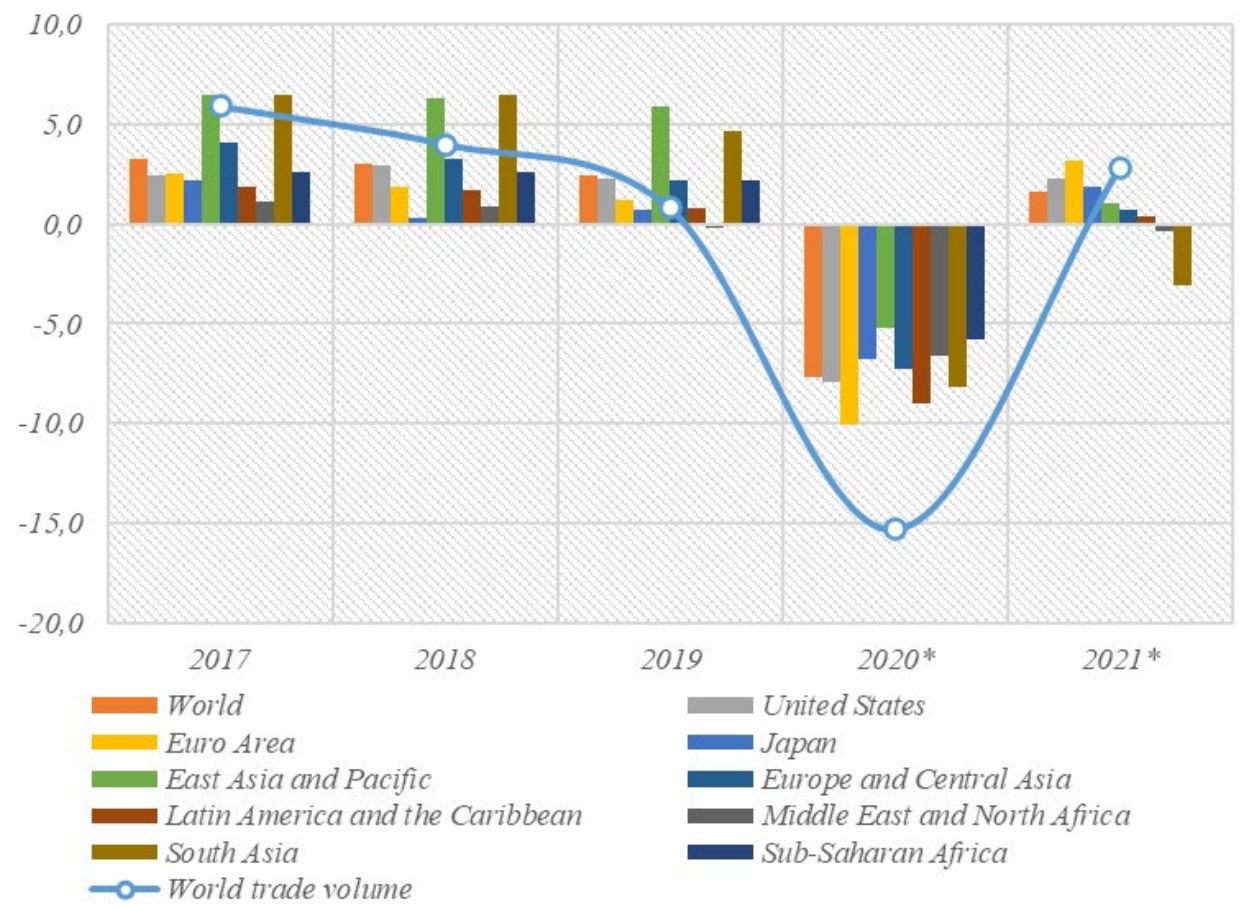

Fig. 2. Changes in the real GDP in the regional context. 


\subsection{Volume of cargo and number of passengers transported by water transport}

Ukraine has significant potential for the development of freight and the number of passengers transported by both maritime and inland water transport. According to the State Statistics Service of Ukraine [21] at the end of 2019 - beginning of 2020 in the State Ship Register of Ukraine registered 694 seagoing vessels (passenger - $4.02 \%$; tankers $-0.83 \%$, dry cargo - 39.22\%; special purpose - $26,02 \%$, technical $-7.43 \%$, service and support $18.68 \%$, fishing $-3.69 \%$ ), 1284 river vessels (passenger $-11.85 \%$, dry cargo $-32.48 \%$, special purpose $-18.34 \%$, technical $-7.64 \%$, service and support $-29.69 \%$;), 184 vessels of the mixed navigation area, as well as about 119.1 thousand pleasure boats.

According to the Ministry of Infrastructure [22], the seaport system of Ukraine has 13 seaports located on the continental territory of Ukraine. Their total capacity is 313.3 million tons. The capacity utilization of Ukrainian ports averages only $43 \%$ to $51 \%$. Ukraine also has 16 river ports and terminals with a total capacity of 60 million tons of cargo per year. The total length of navigable rivers in Ukraine is more than 4 thousand $\mathrm{km}$ - the Dnieper, Danube, and Southern Bug. The Danube is the second-longest, and the Dnieper is the fourth-longest river in Europe. All navigable rivers in Ukraine have access to the Black Sea. The operational length of public inland waterways over the past 30 years has decreased by $60 \%$ from 3,915 thousand $\mathrm{km}$ in 1991 to almost 1,569.4 thousand $\mathrm{km}$ today.

According to Baker Tilly [23], transporting goods using 1 liter of fuel per $1 \mathrm{~km}$ by water transport is 2.54 times more efficient than road transportation and 1.3 times more efficient than railway transportation. At the same time, analyzing the data of the State Statistics Service of Ukraine [24, 25], it can be argued that in the structure of cargo transportation the share of maritime transport over the past 30 years ranged from $0.73 \%$ to $0.2 \%$, inland water transport - from $1 \%$ to $0.24 \%$. The share of water transport in the structure of passenger transportation is even smaller. Over the last 30 years, the share of inland water transport has decreased from $0.19 \%$ to $0.01 \%$, and the share of maritime transport has decreased from $0.22 \%$ to almost zero percent. At the same time, the share of road transport ranges from $72.8 \%$ to $79.6 \%$ in goods transportation and from $41.7 \%$ to $59.6 \%$ in passenger's transportation.

The largest volume of goods was transported by maritime transport of Ukraine (Fig. 3) in 1988 and amounted to $62,560.3$ thousand tons. By 1991, it had decreased by $29.7 \%$ and amounted to 44,002.3 thousand tons. After that, there is a steady trend to reduce the volume of goods transportation by maritime transport in Ukraine. The lowest value, which amounted to 3,698 thousand tons, was observed in 2018 , which was only $8.4 \%$ of the volume in 1991 (i.e. $-91.6 \%$ ) [24].

Most of the transportation of goods by maritime transport in Ukraine is packing and piece freight (from 55\% in 2016 to $68 \%$ in 2020), among which ferrous metals occupy from 65 in 2016 to $86 \%$ in 2020; food freight (from 1\% in 2016 to $7 \%$ in 2020). At the same time, the share of motor vehicles and crane trucks decreased from $23 \%$ in 2016 to less than $1 \%$ of packing and piece freight in 2020 [26]. The share of bulk freight is from 31 to $36 \%$ of the total amount of cargo transported by maritime transport. Among them are grain and milling products. Their share increased from $10 \%$ in 2016 to almost $70-72 \%$ in 2019 and 2020. The share of construction freight also increased from $7 \%$ in 2016 to $33 \%$ in 2020 . The share of ore, on the other hand, decreased from $73 \%$ in 2016 to less than $1 \%$ in 2020 . The share of liquid freight (oil and oil products) during 2016-2020 fluctuates within $1 \div 2 \%$ of the total volume of cargo transported by maritime transport. More than half (from $64 \%$ in 2018 to $51 \%$ in 2020 ) of goods transported by maritime transport in Ukraine were transported abroad. The share of goods transported by maritime transport in Ukraine in domestic traffic ranged from $36 \%$ in 2018 to $49 \%$ in 2020 . 
Approximately the same trends were observed in the transportation of goods by inland water transport of Ukraine [27]. Thus, the highest volumes of these shipments were observed in 1986 and amounted to 67,353.7 thousand tons of cargo. By 1991, the volume of cargo transportation by inland water transport of Ukraine decreased by $10.7 \%$ and amounted to $60,165.1$ thousand tons. Further, there was a sharp decline in the volume of goods transportation by inland water transport until 1996. Then there was a gradual increase in the volume of such traffic until 2007. The smallest volumes of cargo $(2,840.5$ thousand tons) were transported by inland water transport of Ukraine in 2013. From 2014 to 2019 , there was a tendency to slightly increase the volume of goods transportation by this mode of transport. In 2019, the volume of goods transportation was equal to 3,990.2 thousand tons. Compared to 2013 , there was an increase in inland water transport by $40 \%$. At the same time, the general decline in transportation volumes compared to 1991 was $93.4 \%[24]$.

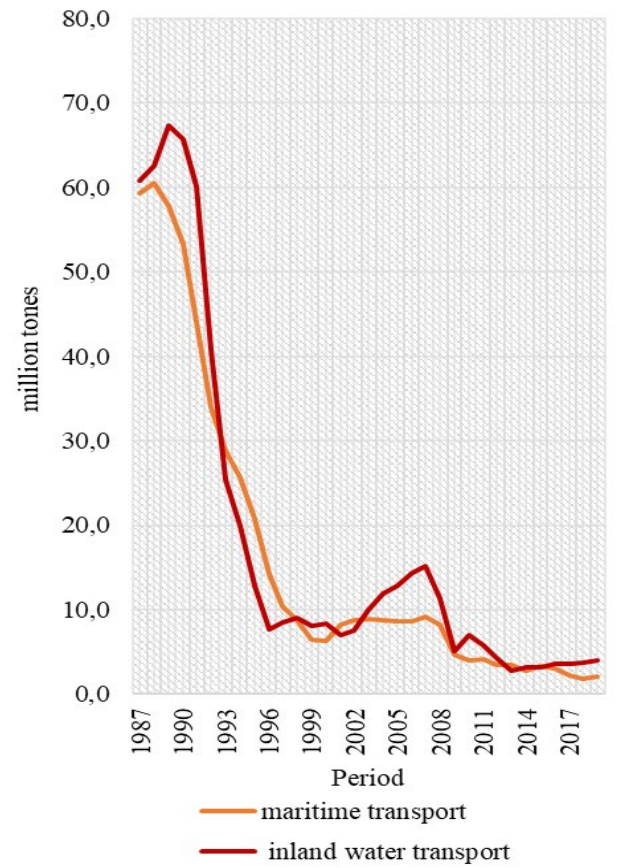

a) Volume of transported goods

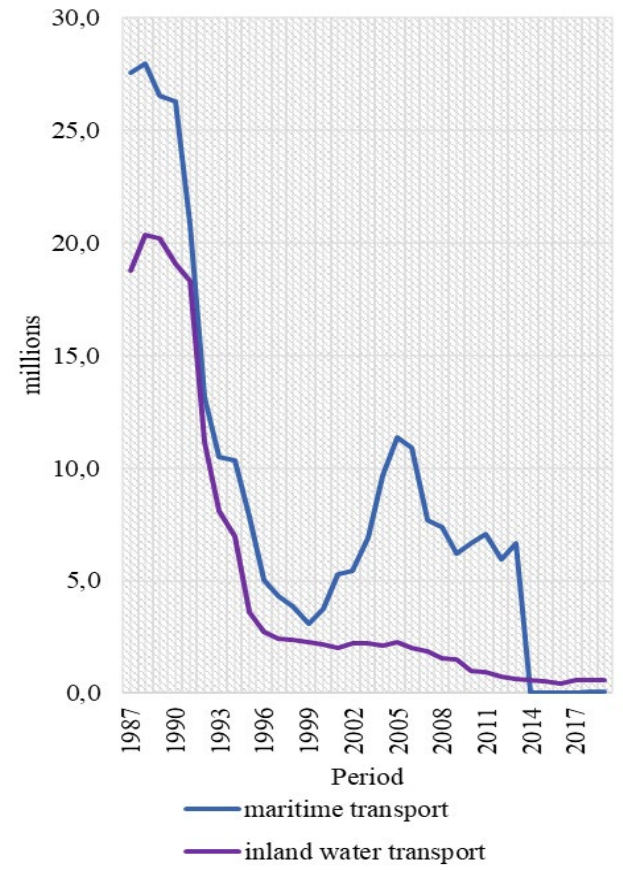

b) Number of passengers

Fig. 3. Changes in volume of goods and number of passengers transported by water transport in Ukraine.

The largest number of passengers transported by maritime transport was observed in 1988 and was equal to 27,961.5 thousand people. By 1991, there was a significant reduction in the number of passengers transported by maritime transport in Ukraine (by $25.7 \%$ ) to $20,786.5$ thousand people. The reduction in the number of passengers transported by maritime transport was observed until 1999 (3084.3 thousand people, i.e. $-85.2 \%$ compared to 1991). From 2000 to 2005, the number of passengers transported by maritime transport increased to $11,341.2$ thousand people ( $+267.7 \%$ compared to 1999). Further, there was a tendency to reduce the number of passengers transported by this mean of transport almost 2 times by 2013. And in 2014 there was a sharp decline in the number of passengers transported by maritime transport in Ukraine almost 226 times (from 6,642 
thousand people in 2013 to 29.4 thousand people in 2014). After that, we can observe a slight increase in the number of passengers (up to 589.9 thousand people in 2019) transported by maritime transport in Ukraine. The total decrease in passenger traffic by the sea in Ukraine compared to 1991 is $-99.6 \%$. [25]

Transportation of passengers by inland water transport is characterized by a steady downward trend. The largest volume of traffic was observed in 1988 and was equal to $20,345.5$ thousand people. Then, by 1996, there was a significant decrease in traffic by almost $86.5 \%$. From 1996 to 2019, the number of passengers transported by inland water transport in Ukraine decreased by 4.6 times. The total decrease in the number of passengers transported by inland water transport compared to 1991 is $-96.8 \%$.

\subsection{Analysis of the dependence of GDP on the volume of goods and the number of passengers transported by water transport}

After systematizing the data obtained as a result of studying the dynamics of GDP, the volume of goods, and the number of passengers transported by water transport of Ukraine and their analysis, we were able to build the dependence model of the GDP volume index $(Y), \%$ on the volume of goods and number of passengers transported by water transport in Ukraine, which can be characterized by such indicators as the volume of goods transported by maritime transport of Ukraine $\left(X_{M V}\right)$, million tons; the number of passengers transported by maritime transport of Ukraine $\left(X_{M P}\right)$, million people; the volume of goods transported by inland water transport of Ukraine $\left(X_{R V}\right)$, million tons; the number of passengers transported by inland water transport of Ukraine $\left(X_{R P}\right)$, million people and record it mathematically. We have established that for Ukraine the dependence of the GDP volume index on the above factors may be as follows:

$$
Y=2.51+0.785 X_{M V}+0.786 X_{R V}+0.961 X_{M P}+1.66 X_{R P}
$$

We investigated the bond density between the GDP volume index and the factors that affect it, checked the quality of the built model, calculated the key indicators, and conducted some special tests.

First of all, the coefficient of determination, $R^{2}$, which is a measure of bond density, was determined. The closer $R^{2}$ is to 1 , the tighter the relationship between the features. $R^{2}=$ 0.6311 . The bond density is moderate.

An empirical correlation, $R$ in our case, shows which part of $Y$ is related to influencing factors (coincides with the correlation index). The closer this figure is to one, the closer the relationship between the signs. $R=0.7944$ - bond density is high.

Fisher's criterion (F-criterion) of our model is equal to $3.47>2.71$. The actual Fcriterion must be greater than the theoretical $\mathrm{F}_{\mathrm{T}}$-criterion (with a probability of 0.95 and $k_{1}=4$ та $\left.k_{2}=28 F_{T}=2.71\right)$.

Root Mean Square Error (Root MSE) characterizes how densely the data is concentrated around the regression line - the standard deviation of the balances, forecast errors. Root $M S E=2.1448$. Root $M S E \rightarrow 0$. Relationship density is statistically significant.

Next, we calculate the p-value of the model. The smaller p-value, the more significant the expected value of the result. In our case, this indicator is equal to $0.0202 \leq 0,05-$ the relationship density is statistically significant.

After that, Pearson's correlation coefficients were significant - the coefficients of pairwise correlation of all variables of the model. The closer the value is to $1(-1)$, the closer the relationship between the model variables. In our case $r_{X M V}=0.6264 ; r_{X R V}=0.5879 ; r_{X M P}$ $=0.5462 ; r_{X R P}=0.5935-$ the relationship density between model variables is moderate. 
The model specification was checked by "Linktest" for the absence of a model specification error. According to the results of the calculations, $p_{\text {hats }}=0.213>0.05-$ the specification of the model is correct.

To test the model for the heterogeneity of observations, which is expressed in the unequal variance of the random error of the regression model, we performed the BreuschPagan/Cook-Weisberg test for heteroskedasticity. According to the results of the calculations $p_{\text {chi2 }}=0,1844>0.05$ - heteroskedasticity is absent.

Verification of the model for the presence of a linear relationship between the explanatory variables (multicollinearity) was performed using the calculation of variance inflation factor $(V I F)$. According to the results of calculations Mean $V I F=2.5676<10$; $V I F_{X M V}=3.91<10\left(1 / V I F_{X M V}=0.255754>0.1\right) ; V I F_{X R V}=2.76<10\left(1 / V I F_{X R V}=0.362319\right.$ $>0.1) ; V I F_{X M P}=1.87<10\left(1 / V I F_{X M P}=0.534759>0.1\right) ; V I F_{X R P}=1.73<10\left(1 / V I F_{X R P}=\right.$ $0.578035>0.1)$ - multicollinearity is absent.

The procedure for checking the autocorrelation of an arbitrary order in random errors of the regression model was performed using the Cumby-Huizinga test for autocorrelation (Breusch-Godfrey). According to the results of the calculations $p_{1}=0,1844>0.05-$ autocorrelation is absent.

To test the null hypothesis that the data of the analyzed time series are stationary around the deterministic trend against the single root alternative, a stationarity test (KwiatkowskiPhillips-Schmidt-Shin test) was performed. According to the results of the calculations: $0.187=T S_{Y}<C V_{Y}^{1 \%}=0.216 ; 0.175=T S_{X M V}<C V_{X M V}{ }^{1 \%}=0.216 ; 0.151=T S_{X R V}<C V_{X R V}{ }^{1 \%}$ $=0.216 ; 0.124=T S_{X M P}<C V_{X M P}{ }^{1 \%}=0.216 ; 0.166=T S_{X R P}<C V_{X R P}{ }^{1 \%}=0.216-$ the data of the time series under analysis are stationary.

The results of the analysis of the relationship density between the GDP volume index, the volume of goods, and the number of passengers transported by water in Ukraine show that the regression model is qualitative and can be used for the GDP volume index forecasting.

\section{Discussion}

Thus, the baseline forecasting scenario (Y_base line) was calculated using the Holt winters seasonal smoothing method taking into account the trends of socio-economic development of Ukraine with the impact of the spread of acute respiratory disease COVID-19 in 2020, other things being equal.

This scenario envisages the implementation of the benchmarks set for target indicator 9.1.2 (SDG 9) and the maintenance of existing trends regarding the partial implementation of target indicator 9.1.3 (SDG 9). The results of the calculations show only a partial implementation of the benchmarks set for target indicator 8.1.1 (SDG 8) to increase the GDP index volume only by $25 \div 30 \%$ of the set benchmark (Fig. 4 ).

The following scenario ( $\mathrm{Y} \_$part line) assumes, taking into account the impact of the spread of acute respiratory disease COVID-19, only partial fulfillment of target indicator 9.1.2 (SDG 9) and complete non-fulfillment of target indicator 9.1.3 (SDG 9). According to the results of the calculations, this may lead to a sharp decline in GDP and a slowdown in its growth in the future.

The pessimistic forecast (Y_pes line) was determined taking into account the opinion of experts $[28,29]$, which predict a decline in global socio-economic development on average from 3 to $10 \%$ annually. According to this scenario, the annual decline in the volume of freight and number of passengers transported by all modes of transport is expected. Under such conditions, there may be a complete non-fulfillment of tasks 9.1.2, 9.1.3 (SDG 9) and, as a consequence, non-fulfillment of task 8.1.1 (SDG 8) to increase the GDP volume index. 
Optimistic scenario (Y_opt line) - was determined using the model built by the authors, taking into account the Forecast of Economic and Social Development of Ukraine for 20212023 developed by the Ministry for Development of Economic, Trade, and Agriculture of Ukraine, which was approved by the Cabinet of Ministers of Ukraine Decree from July 29, 2020, number 671 [30]. It aims to form an idea of the most likely "restart" of the economy after the spread of acute respiratory disease COVID-19 caused by the coronavirus SARSCoV-2 [18]. According to the authors' calculations, for this scenario, it is envisaged to achieve the benchmarks set for tasks 9.1.2 and 9.1.3 (SDG 9) in full, provided that the existing structure of goods and passengers transportation by all mode of transport preserve. Even within such a structure of transportation, the increase in the volume of goods and number of passengers transported by maritime and inland water transport (other things being equal) provides an approximation of $68.1 \div 72.3 \%$ to meet the benchmark set for task 8.1.1 (SDG 8) to increase the GDP volume index. Therefore, there is a need to increase the share of maritime and inland waterway transport in the overall structure of freight and passenger traffic without reducing the volume of transportation by other modes of transport.

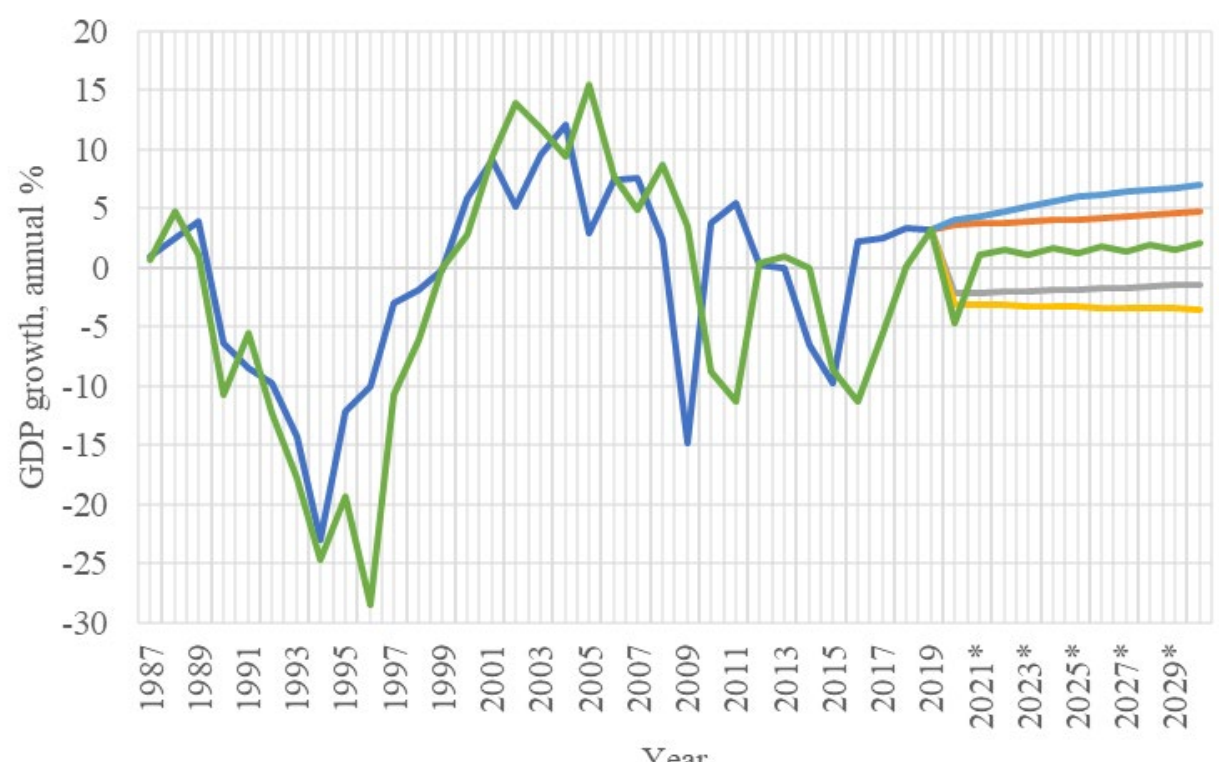

$\longrightarrow \mathrm{Y} \longrightarrow \mathrm{Y} \_$opt $\longrightarrow \mathrm{Y}$ part $\longrightarrow \mathrm{Y}$ pes $\longrightarrow \mathrm{Y}$ benchmark $-\mathrm{Y} \_$base

Fig. 4. Forecasting the values of the GDP volume index in Ukraine: $\mathrm{Y}$ - actual values of the index of physical volume of GDP; Y_opt - optimistic forecasting scenario; Y_part - forecasting scenario under the condition of partial fulfillment of sustainable development targets; $Y$ _pes - pessimistic forecasting scenario; Y_benchmark - benchmarks for sustainable development; Y_base - baseline forecasting scenario.

Summing up, we can see that not all elements of the business environment of water transport are uniform. Even its most global elements crystallize locally and affect each business entity differently. Such properties cover numerous measurements. For a deep understanding of the impact of changes in the volume of goods and the number of passengers transported by water on the GDP of Ukraine, we need a global and systematic perspective of its study. 


\section{Conclusions}

Thus, based on the built economic and mathematical model, we can say that an increase in maritime freight by 1 million tons (subject to the consolidation of the influence of other predictors) will increase the GDP volume index by $0.785 \%$; when the volume of passengers transported by sea increases by 1 million people (subject to the consolidation of the influence of other predictors), there will be an increase in the GDP volume index by $0.961 \%$; with the increase in the volume of goods transportation by inland water transport by 1 million tons (subject to the consolidation of the influence of other predictors) there will be an increase in the GDP volume index by $0.786 \%$; with the increase in the number of passengers transported by inland water transport by 1 million people (subject to the consolidation of the influence of other predictors), there will be an increase in the GDP volume index by $1.66 \%$.

Four main scenarios of the impact of changes in the volume of goods and number of passengers transported by water on the GDP of Ukraine were calculated using the developed model. Thus, while maintaining the existing trends in the development of maritime and inland water transport in Ukraine, non-fulfillment or partial fulfillment of sustainable development benchmarks for the volume of goods and number of passengers transported may lead to non-compliance with sustainable development benchmarks for GDP growth. At the same time, only an increase in the volume of goods and number of passengers, transported by water, provided that the benchmarks set for the indicators 9.1.2 and 9.1.3 (SDG 9) are met, can provide an approach to the benchmark, which is set for the indicator 8.1.1 (SDG 8), by approximately 70\%. Besides, the use of water transport (both maritime and inland water transport) in comparison with other modes of transport has the lowest cost of transportation per 1 ton of cargo and provides greater efficiency and environmental friendliness (including by reducing emissions of pollutants into the atmosphere). Therefore, according to the authors, to increase the value of indicators 9.1.2 and 9.1.3 is due to the increase in the volume of goods and number of passengers transported by water, most meet the conditions of target 9.1 implementation (SDG 9).

Further research in this area will make it possible to assess the competitiveness of water transport in Ukraine and to develop recommendations for its integration into the European transport network.

\section{References}

1. Shevchenko, H., Petrushenko, M., Burkynskyi, B., \& Khumarova, N. (2021). SDGs and the ability to manage change within the European green deal: The case of Ukraine. Problems and Perspectives in Management, 19(1), 53-67. http://dx.doi.org/10.21511/ppm.19(1).2021.05

2. Laiko, O., Kovalenko, S., \& Bilousov, O. (2020). Prospects for the development of cluster forms of entrepreneurship in Euroregions. Baltic Journal of Economic Studies, 6(5), 118-128. https://doi.org/10.30525/2256-0742/2020-6-5-118-128

3. Kelle, P., Song, J., Jin, M., Schneider, H., \& Claypool, C. (2019). Evaluation of operational and environmental sustainability tradeoffs in multimodal freight transportation planning. International Journal of Production Economics, 209, 411-420. https://doi.org/10.1016/j.ijpe.2018.08.011

4. Ilchenko, S. (2017). Economic conditions of the functioning and existence of asymmetry in the development of transport services markets of Ukraine. Problems and Perspectives in Management, 15 (1), 93-98. 
5. Wu, C.-Y., Heiets, I., \& Shvindina, H. (2020). Business Model Management of LowCost: in a Search for Impact-Factors of Performance (Case of AirAsia Group Airlines). Marketing and Management of Innovations, 2, 354-367. http://doi.org/10.21272/mmi.2020.2-26

6. Nitsenko, V., Kotenko, S., Hanzhurenko, I., Mardani, A., Stashkevych, I., \& Karakai, M. (2020). Mathematical Modeling of Multimodal Transportation Risks, 439-447. In: Ghazali R., Nawi N., Deris M., Abawajy J. (eds) Recent Advances on Soft Computing and Data Mining. SCDM 2020. Advances in Intelligent Systems and Computing, 978. Springer, Cham. https://doi.org/10.1007/978-3-030-36056-6_41

7. Nitsenko, V., Mardani, A., Streimikis, J., Shkrabak, I., Klopov, I., Novomlynets, O., \& Podolska, O. (2018). Criteria for Evaluation of Efficiency of Energy Transformation Based on Renewable Energy Sources. Montenegrin Journal of Economics, 14(4), 253263. https://doi.org/10.14254/1800-5845/2018.14-4.17

8. Koval, V., Duginets, G., Plekhanova, O., Antonov, A., \& Petrova, M. (2019). On the supranational and national level of global value chain management. Entrepreneurship and Sustainability Issues, 6(4), 1922-1937. https://doi.org/10.9770/jesi.2019.6.4(27)

9. Yankovyi, O., Goncharov, Yu., Koval, V., \& Lositska, T. (2019). Optimization of the capital-labor ratio on the basis of production functions in the economic model of production. Naukovyi Visnyk Natsionalnoho Hirnychoho Universytetu, 4, 134-140.

10. Gryshchenko, V., Dreval, O., \& Gryshchenko, I. (2015) Regional Export-Import Potential Use Management Within The System of Ecological and Economic Security. Actual Problems in Economics, 8(170), 226-238.

11. State Statiatics Service of Ukraine. (2020). Sustainable Development Goals: Ukraine 2020. Monitoring Report. Kyiv: State Statiatics Service of Ukraine. http://www.ukrstat.gov.ua

12. Department for Strategic Planning and Macroeconomic Forecasting. (2020). Sustainable Development Goals: Ukraine. Voluntary National Review. Kyiv: Ministry for Development of Economy, Trade and Agriculture of Ukraine. https://sustainabledevelopment.un.org/content/documents/26295VNR_2020_Ukraine Report.pdf

13. State Statiatics Service of Ukraine. (2020). Gross domestic product by income categories. http://www.ukrstat.gov.ua/operativ/operativ2005/vvp/vvp_ric/arh_svvpzkd u.htm

14. The World Bank. (2020). World Development Indicators Statistical Tables: GDP growth. http://api.worldbank.org/v2/en/indicator/NY.GDP.MKTP.KD.ZG?downloadfo $\underline{\text { rmat }=\text { excel }}$

15. The World Bank. (2020). World Development Indicators Statistical Tables: GDP. http://api.worldbank.org/v2/en/indicator/NY.GDP.MKTP.CD?downloadformat=excel

16. State Statiatics Service of Ukraine. (2020). Gross Domestic Product. http://www.ukrstat.gov.ua/operativ/operativ2020/vvp/vvp_rik/arh_vvp_rik_90-18u.htm

17. International Bank for Reconstruction and Development. (2020). Global economic prospects: June 2020. Washington: The World Bank. https://openknowledge.worldbank.org/bitstream/handle/10986/337448/9781464815539. pdf

18. Department for Strategic Planning and Macroeconomic Forecasting. (2020). The Forecast of economic and social development of Ukraine for 2021-2023. Kyiv: Ministry for Development of Economy, Trade and Agriculture of Ukraine. https://www.me.gov.ua 
19. National Bank of Ukraine. (2020). Shadow economy in Ukraine. https://bank.gov.ua/ua/news/all/doslidjennya-tinovoyi-ekonomiki-v-ukrayini--mayjechvert-vvp--abo-846-mlrd-griven--perebuvaye-v-tini

20. Department for Strategic Planning and Macroeconomic Forecasting. (2020). General trends of the shadow economy in Ukraine in 2019. Kyiv: Ministry for Development of Economy, Trade and Agriculture of Ukraine.

21. State Statiatics Service of Ukraine. (2020). Transport of Ukraine 2019. Kyiv: State Statiatics

Service of

Ukraine. https://ukrstat.org/uk/druk/publicat/kat u/2020/zb/10/zb trans_19.pdf

22. The Ministry of Infrastructure of Ukraine. (2020). General information about water transport of Ukraine. https://mtu.gov.ua/en/content/hto-mi-e.html

23. Baker Tilly Ukraine. (2020). River logistics of Ukraine on the threshold of change. https://bakertilly.ua/ru/news/id38556

24. State Statiatics Service of Ukraine. (2020). Volume of transported goods by types of transport. http://www.ukrstat.gov.ua/operativ/operativ2018/tr/tr_rik/tr_rik_u/op_vant vt u.htm

25. State Statiatics Service of Ukraine. (2020). Number of transported passengers by types of transport. http://www.ukrstat.gov.ua

26. State Statiatics Service of Ukraine. (2020). Freight transportation by see transport and type of freight. http://www.ukrstat.gov.ua/operativ/operativ2020/tr/pv_mor/pv_mor_u/ arh_pv mor 20 u.htm

27. State Statiatics Service of Ukraine. (2020). Freight transportation by river transport and type of freight. http://www.ukrstat.gov.ua/operativ/operativ2020/tr/pv_rich/pv_rich _u/arh_pv_rich_20u.htm

28. World Economic Forum. (2020). Challenges and Opportunities in the Post-COVID-19 World: Insight Report. Geneva: World Economic Forum.

29. Department for Strategic Planning and Macroeconomic Forecasting. (2020). Ukraine: the impact of COVID-19 on the economy and society (vision of post-pandemic development in 2020-2024 through the eyes of experts and youth): Consensus forecast. Kyiv: Ministry for Development of Economy, Trade and Agriculture of Ukraine. https://www.me.gov.ua

30. The Cabinet of Ministers of Ukraine. (2020). On approval of the Forecast of economic and social development of Ukraine for 2021-2023 (Order no. 671, amended effective July 29, 2020). https://zakon.rada.gov.ua/laws/show/671-2020-\%D0\%BF\#Text 